\title{
Large surface meltwater discharge from the Kangerlussuaq sector of the Greenland ice sheet during the record-warm year 2010 explained by detailed energy balance observations
}

\author{
D. van $\mathrm{As}^{1}$, A. L. Hubbard ${ }^{2}$, B. Hasholt ${ }^{3}$, A. B. Mikkelsen $^{3}$, M. R. van den Broeke ${ }^{4}$, and R. S. Fausto ${ }^{1}$ \\ ${ }^{1}$ Geological Survey of Denmark and Greenland, Øster Voldgade 10, 1350 Copenhagen K, Denmark \\ ${ }^{2}$ Institute of Geography and Earth Sciences, Aberystwyth University, Llandinam Building, Penglais Campus, Aberystwyth, \\ SY23 3DB, Wales \\ ${ }^{3}$ Department of Geography and Geology, Øster Voldgade 10, 1350 Copenhagen K, Denmark \\ ${ }^{4}$ Institute for Marine and Atmospheric Research, Utrecht University, Princetonplein 5, 3584 CC Utrecht, The Netherlands
}

Correspondence to: D. van As (dva@geus.dk)

Received: 15 August 2011 - Published in The Cryosphere Discuss.: 6 September 2011

Revised: 28 December 2011 - Accepted: 3 January 2012 - Published: 13 February 2012

\begin{abstract}
This study uses data from six on-ice weather stations, calibrated MODIS-derived albedo and proglacial river gauging measurements to drive and validate an energy balance model. We aim to quantify the record-setting positive temperature anomaly in 2010 and its effect on mass balance and runoff from the Kangerlussuaq sector of the Greenland ice sheet. In 2010 , the average temperature was $4.9^{\circ} \mathrm{C}$ (2.7 standard deviations) above the 1974-2010 average in Kangerlussuaq. High temperatures were also observed over the ice sheet, with the magnitude of the positive anomaly increasing with altitude, particularly in August. Simultaneously, surface albedo was anomalously low in 2010, predominantly in the upper ablation zone. The low albedo was caused by high ablation, which in turn profited from high temperatures and low winter snowfall. Surface energy balance calculations show that the largest melt excess $(\sim 170 \%)$ occurred in the upper ablation zone (above $1000 \mathrm{~m}$ ), where higher temperatures and lower albedo contributed equally to the melt anomaly. At lower elevations the melt excess can be attributed to high atmospheric temperatures alone. In total, we calculate that $6.6 \pm 1.0 \mathrm{~km}^{3}$ of surface meltwater ran off the ice sheet in the Kangerlussuaq catchment in 2010, exceeding the reference year 2009 (based on atmospheric temperature measurements) by $\sim 150 \%$. During future warm episodes we can expect a melt response of at least the same magnitude, unless a larger wintertime snow accumulation delays and moderates the melt-albedo feedback. Due to the hypsometry of the ice sheet, yielding an increasing surface area with elevation, meltwater runoff will be further amplified by increases in melt forcings such as atmospheric heat.
\end{abstract}

\section{Introduction}

Greenland stores nearly three million cubic kilometres of ice, a large potential contribution to sea level rise. In recent years, increasingly large areas of the ice sheet have been losing mass, as determined from its satellite-derived gravity field (e.g. Khan et al., 2010; Schrama et al., 2011). Whereas the retreat and thinning of numerous marine-terminating glaciers has not been limited to recent years (Csatho et al., 2008), the acceleration of many major outlets and consequent increase in iceberg discharge is, and has become a significant component of the overall net mass loss in the last decade (Rignot and Kanagaratnam, 2006; Howat et al., 2011). However, mass loss is not confined to regions with marine-terminating glaciers. Large sections of the land-terminating ice sheet margin are known to be subject to thinning (Pritchard et al., 2009), as a direct and potentially indirect consequence of increasing surface melt. Roughly half of recent Greenland ice sheet mass loss can be attributed to increases in surface melt (Van den Broeke et al., 2009), which reaffirms the importance of surface mass balance (SMB) monitoring.

Temperatures in Greenland have been monitored since the 1870s (DMI technical report 11-15). After a 40-yr cooling period, a warming trend set in since the 1980s (Box, 2002). The most rapid warming on record occurred during the 1990s, and the last decade has seen several record-setting years in various Greenland sectors, though predominantly on the west coast. However, 2010 was the warmest year across Greenland (barring the northeast) since meteorological observations began (DMI technical report 11-15; Box et al., 2011). The combined effect of high temperature and 
low precipitation on 2010 ablation and the albedo feedback functioning as an amplifier, has been discussed by Tedesco et al. (2011), Van den Broeke et al. (2011) and Van As et al. (2011).

In this paper we investigate the spatial and temporal variability of the surface energy and mass balances over the Kangerlussuaq sector of the southwest Greenland ice sheet, using data from an automatic weather station (AWS) network of unprecedented density for Greenland, allowing accurate interpolation over the entire catchment. We use a surface energy balance (SEB) model that resolves all energy fluxes and has proven to provide realistic results for various snow and ice surfaces. We improve upon models that use a constant or calculated snow and ice albedo by the inclusion of calibrated MODIS-derived values; surface albedo has a dominant influence on melt, but its spatiotemporal variability cannot be modelled with great accuracy. We demonstrate the accuracy of local and catchment-wide results by three-fold validation, most importantly by comparison to discharge measurements in the proglacial river that collects meltwater runoff. In light of the extraordinary atmospheric conditions in Greenland in 2010, we quantify the 2010 temperature and MODIS-derived as albedo anomalies. Subsequently, we calculate the SEB and meltwater runoff, and investigate the causes for the large melt totals. We focus entirely on the Kangerlussuaq region to take full advantage of the wealth of observational data in the region, adding to the interpretation of larger scale but less well constrained studies based on, e.g. regional climate model output. This study not only provides a detailed understanding of the impact of atmospheric forcings on the Greenland ice sheet and the role played by the hypsometry, but also freshwater availability for penetration to the bed and into the bedrock, which is one of the main research aims of the Greenland Analogue Project (GAP).

\section{Methods}

\subsection{Observations}

The Kangerlussuaq region of the Greenland ice sheet has a high density of AWS on the otherwise scarcely instrumented ice sheet (Fig. 1), and therefore is an attractive location to investigate factors influencing the SMB and meltwater runoff. Here, the Institute for Marine and Atmospheric Research in Utrecht (IMAU) has been running three AWS since 2003 (S5, S6 and S9). In 2008 and 2009, the Geological Survey of Denmark and Greenland (GEUS) added three stations to the transect (KAN_L, KAN_M and KAN_U) as part of GAP; see Table 1 for station metadata. The equilibrium line in this region is situated at a relatively high altitude of $\sim 1500 \mathrm{~m}$ (Van de Wal et al., 2005), thus five AWS are located in the ablation zone. KAN_U is placed well into the accumulation zone, though melt does occur there at the peak of the melt season. We tested the possibility of extending our region of interest to the ice divide by including the Greenland Climate Network (GC-Net) stations DYE-2 and Saddle (resp. 66 and $158 \mathrm{~km}$ southeast of KAN_U), but found a relatively poor correlation between those stations and the ones included in the study (e.g. $r=0.75$ and 0.06 between KAN_U and Saddle for daily means of wind speed and relative humidity, respectively). Including these in the study could complicate the interpretation of results with little impact on melt.

For melt calculations we make use of the following weather-station observations at $2-3 \mathrm{~m}$ above the surface: air pressure, air temperature, relative humidity, wind speed, and downward shortwave/solar and longwave/terrestrial radiation. Upward shortwave and longwave radiation, and surface height change due to accumulation and ablation are used for calibration and validation purposes (see below). The horizontal distances between the six AWS are 8 to $54 \mathrm{~km}$, increasing with decreasing surface slope. We spatially interpolate daily-mean AWS observations into $100 \mathrm{~m}$ elevation bins to be able to determine the distributed melt patterns in the region. A linear least-squares fit to the AWS measurements for each time step was utilized since this method also allows reliable extrapolation.

Surface albedo is a principal input variable, which cannot be interpolated from AWS observations alone due to its inherent spatial heterogeneity. Therefore daily MOD10A1 albedo data from the Moderate Resolution Imaging Spectroradiometer (MODIS) on NASA's Terra satellite (Hall et al., 2006; Klein and Stroeve, 2002) were used. MOD10A1 data were validated using GC-Net AWS data by Stroeve et al. (2006), who reported a root mean square (RMS) error of 0.067 and correlation of 0.79 . Issues with the MODIS albedo product over Greenland snow surfaces for large zenith angles were identified by Wang and Zender (2010) (commented on by Schaaf et al., 2011). We applied corrections to remove sensitivity to the solar zenith angle as identified by comparing the MODIS data to the observed albedo at the AWS in the Kangerlussuaq catchment, reducing the RMS error from 0.114 to 0.079 with a correlation coefficient of 0.75 . The need for a correction of the MODIS albedo product was also identified by Tedesco et al. (2011), who used MCD43 data and stated that the disagreement with AWS observations results from the spatial scale of the MODIS tiles, atmospheric corrections, and the MODIS retrieval algorithm. We consider our approach a step towards MODIS validation over Greenland bare ice surfaces, but mostly a large improvement in regional melt modelling; previous studies assumed ice albedo to be spatiotemporally constant (Mernild et al., 2010), or used a temperature-index (degree-day) model, which do not resolve the energy balance components, thus do not take into account surface albedo (Bartholomew et al., 2011).

River depth and flow velocity data were gathered at Watson River bridge in Kangerlussuaq and converted into freshwater flux with an estimated uncertainty of $20 \%$ for single values (Hasholt et al., 2012), i.e. $5 \%$ larger than the uncertainty reported by Bartholomew et al. (2011). Immediately 


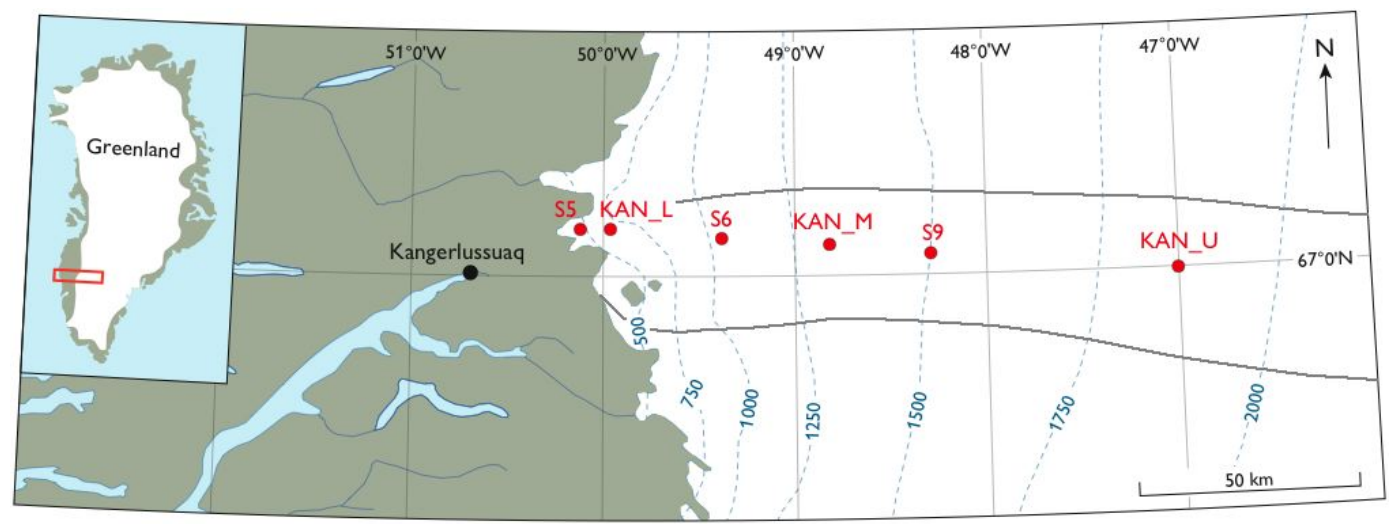

Fig. 1. Map of southwest Greenland including the positions of the automatic weather stations and catchment delineation (grey lines).

Table 1. Metadata for the automatic weather stations on the Greenland ice sheet used in this study.

\begin{tabular}{lllrl}
\hline Station name & Latitude $\left({ }^{\circ} \mathrm{N}\right)$ & Longitude $(\mathrm{W})$ & Elevation $(\mathrm{m})$ & Date of placement \\
\hline S5 & $67^{\circ} 6^{\prime}$ & $50^{\circ} 7^{\prime}$ & 460 & 1 Sep 2003 \\
KAN_L & $67^{\circ} 6^{\prime}$ & $49^{\circ} 56^{\prime}$ & 670 & 1 Sep 2008 \\
S6 & $67^{\circ} 5^{\prime}$ & $49^{\circ} 23^{\prime}$ & 1020 & 1 Sep 2003 \\
KAN_M & $67^{\circ} 4^{\prime}$ & $48^{\circ} 49^{\prime}$ & 1280 & 2 Sep 2008 \\
S9 & $67^{\circ} 3^{\prime}$ & $48^{\circ} 14^{\prime}$ & 1510 & 1 Sep 2003 \\
KAN_U & $67^{\circ} 0^{\prime}$ & $47^{\circ} 1^{\prime}$ & 1830 & 4 Apr 2009 \\
\hline
\end{tabular}

downstream of the bridge, the freshwater from the $25 \mathrm{~km}$ long proglacial river originating at the ice sheet margin enters Kangerlussuaq fjord. Upstream, two proglacial rivers merge, of which the northernmost one originates from the snouts of two officially unnamed glaciers that are known as Russell and Leverett Glaciers, both of which are fed from a larger outlet. The southern arm of the proglacial river emerges from another pair of outlet glaciers that re-converge and flows down what is locally known as the Hidden Valley.

For melt model calculations, the catchment areas of both rivers were taken into account for direct comparison of calculated surface meltwater runoff to observed river discharge at the bridge. From hereon we call the combined areas the "Kangerlussuaq catchment". The delineation of the catchment was not performed with automated hydrological tools such as provided with ArcGIS, as they are inaccurate over smooth surfaces such as an ice sheet where delineation of watersheds can be up to $22.5^{\circ}$ inaccurate for hundreds of kilometres. A testimony of this is the sensitivity of this procedure to the digital elevation model grid projection. Instead, we determined the drainage basin boundaries by hand from our digital elevation model of the ice sheet, which can be done within an estimated $10^{\circ}$ of the surface slope direction. Ideally, the catchment should be delineated from the subglacial topography, since meltwater in the Kangerlussuaq catchment does not run over the ice sheet surface long before a moulin transports it to en- or sub-glacial conduits.
But no map resolving the details of the bedrock topography currently exists. However, we will show below that the results for catchment-wide surface meltwater runoff are insensitive to errors in catchment delineation (max. $13 \%$ inaccurate during extreme melt years), since meltwater production is small in the higher regions of the catchment, where catchment width is least accurate.

\subsection{Surface mass balance model}

Near-surface air temperature impacts melt through the turbulent flux of sensible heat and downward longwave irradiance, so it is only one of the contributors to surface melt of glaciers and ice caps. To accurately determine to what extent the atmospheric conditions in 2010 impacted the nearby ice sheet in the Kangerlussuaq region, we must apply a SEB model resolving all energy fluxes. The model used here is similar to that applied by Van As (2011) and has proven robust and accurate for various snow and ice surfaces in, among others, Greenland high melt regions and the Antarctic plateau. It uses meteorological observations (air pressure, temperature, humidity, wind speed, and downward shortwave and longwave irradiance) to calculate the SEB components (net shortwave radiation (SR), net longwave radiation (LR), sensible heat flux (SH), latent heat flux (LH), sub-surface conductive heat flux (SSH), and heat flux from rain $(R)$ ):

$\mathrm{SR}+\mathrm{LR}+\mathrm{SH}+\mathrm{LH}+\mathrm{SSH}+R=M$ 
Fluxes are defined positive when adding energy to the surface. The left-hand terms in the equation can be constrained by AWS measurements and MODIS-derived surface albedo. The calculation of the turbulent heat fluxes $\mathrm{SH}$ and $\mathrm{LH}$ is based on near-surface gradients of meteorological variables, using the surface as the lower level for gradient calculation, and makes use of well-tested stability correction functions and common values for aerodynamic surface roughness length for momentum $\left(1 \times 10^{-4} \mathrm{~m}\right.$ for snow and $1 \times 10^{-3} \mathrm{~m}$ for ice, Brock et al., 2006). Calculation of SH, LH, SSH, and upward longwave radiation makes use of the unknown variable of surface temperate, for which the equation can be solved iteratively. For periods during which the energy balance components cannot be balanced, which occur when the surface temperature is limited by its melting temperature of $0^{\circ} \mathrm{C}$, the surplus energy $(M)$ is used to calculate snow or ice melt. For more model details we refer to Van As (2011) and the references therein.

The modelled SMB is the sum of solid precipitation, melt, sublimation/deposition, and condensation/evaporation. Liquid precipitation and meltwater produced at the surface refreeze in underlying snow layers if temperature and density requirements are met, i.e. when sub-surface grid cells are at sub-freezing temperatures and not at ice density. The remaining water is assumed to run off. All but one of the mass balance components are products of the energy balance model. Precipitation, however, is unknown, as it is not measured at the AWS on the ice sheet, and cannot be accurately extrapolated from distant or even nearby off-ice measurements due to its high spatial variability. Whereas solid precipitation could be estimated from the accumulation measured at the six AWS, liquid precipitation cannot and has to be parameterized. In our parameterization we prescribe a $1 \mathrm{~mm}$ water equivalent per hour precipitation rate for periods with a heavy cloud cover, which the model identifies from occurrences when downward longwave radiation values exceed blackbody radiation calculated using near-surface air temperature. The precipitation rate is tuned to fit accumulation observations, assuming solid precipitation to occur for subfreezing temperatures.

\subsection{Model uncertainty and validation}

Several factors contribute to the uncertainty in our SEB calculations. Firstly, measurement errors vary per sensor and accumulate, sometimes in non-linear ways, in the SEB calculations. The largest sensor uncertainty, as reported by the manufacturer, is for the Kipp and Zonen CNR1 radiometer (10\% for daily totals, see Van As, 2011), which is actually shown to be smaller (Van den Broeke et al., 2004). Secondly, a number of assumptions are made in our model, most importantly for the aerodynamic surface roughness length. Assuming these to be constant in time is a simplification, as outlined by Smeets and Van den Broeke (2008). Using a daily time step in our model calculations instead of a temporal resolution resolving the daily cycle is justified, given the ablation validation for the AWS positions shown below. Also, a reduced temporal resolution ensures a more robust spatial interpolation of measured variables since local atmospheric variability on short time scales is averaged out. The linear interpolation in itself contributes to model uncertainty; alternatively, it keeps measurement errors by single AWS in check by the measurements of other stations. Finally, in calculating the integrated runoff from the ice sheet, the error in the delineation of the Kangerlussuaq catchment translates directly into runoff errors. In all, the causes of uncertainty in this study are not exceptional and allow for catchment-wide SEB and SMB calculations that are more accurate than in previous studies given the reliance on observational data, in particular on MODIS albedo.

Evaluation of the calculations is performed using three independent methods. Firstly, we require a close agreement between the modelled surface temperatures and those calculated from measured emitted longwave radiation assuming black-body radiative properties. We found RMS difference values of $1.0-1.7^{\circ} \mathrm{C}$ for the six stations and their corresponding elevation bins, which is 4-6 times smaller than the uncertainty derived from the $10 \%$ uncertainty quoted by the radiometer manufacturer. This illustrates that surface temperatures are modelled accurately and that radiometer readings may be more precise than specified by the manufacturer (Van den Broeke et al., 2004). Secondly, in the Results section we compare observed and modelled surface height change due to ablation and accumulation at the AWS sites. Thirdly, we assess the quantitative agreement between the surface meltwater runoff for the Kangerlussuaq catchment and the freshwater discharge measurements at the Kangerlussuaq bridge.

The cumulative ablation at the five AWS in the ablation zone and the model results in the corresponding elevation bins disagree by $4 \%$ in 2009 (the only year with a full set of ablation measurements), although the difference at individual stations can be larger (RMS error of $16 \%$ of the cumulative ablation). If we assume the cumulative AWS ablation measurements to be representative for the runoff from entire catchment, and take into account the uncertainty in catchment size (up to $13 \%$ for extreme melt years such as 2010 , see Results section), we can calculate a model uncertainty for runoff totals of $6-14 \%$.

\section{Results}

\subsection{Temperature}

The meteorological records by the Danish Meteorological Institute (DMI) in the Kangerlussuaq settlement date back to May 1973 and show a mean warming of $0.067^{\circ} \mathrm{C}$ per year (Fig. 2). Whereas the temperature record gives an annualmean value of $-5.0^{\circ} \mathrm{C}$, the 2010 average was $-0.1^{\circ} \mathrm{C}$, 2.7 standard deviations above average. This exceeded 


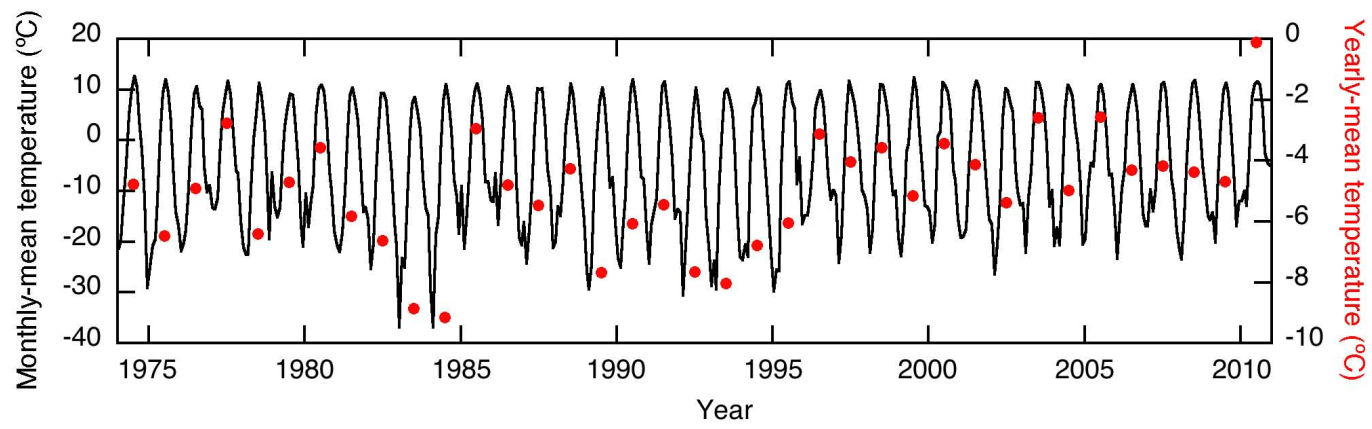

Fig. 2. Monthly-mean (black line) and annual-mean (red dots) temperatures at the Kangerlussuaq settlement.

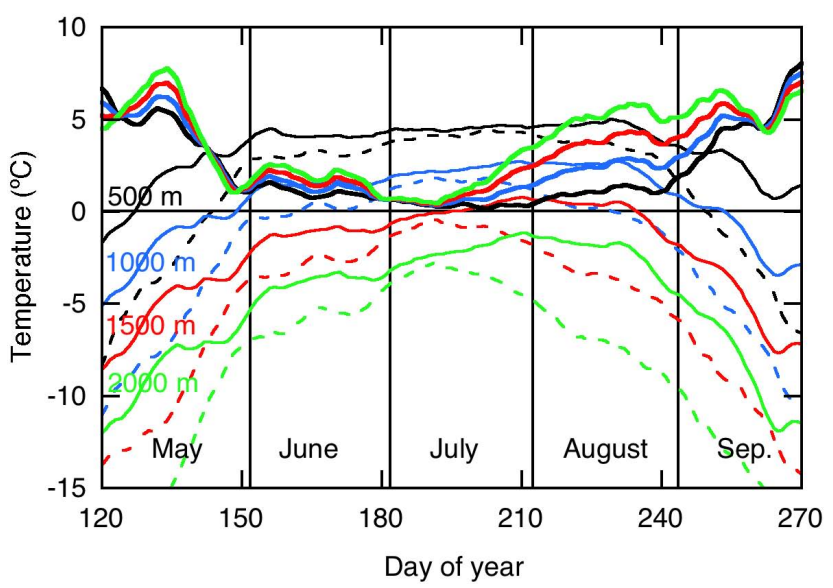

Fig. 3. Thirty-day running average of near-surface air temperature over the ice sheet at $500 \mathrm{~m}$ (black), $1000 \mathrm{~m}$ (blue), $1500 \mathrm{~m}$ (red) and $2000 \mathrm{~m}$ (green) elevation above sea level for 2009 (dashed lines) and 2010 (solid lines). Thick lines illustrate the 2010-2009 difference with the same colour coding.

both the second (2005) and third (2003) warmest years by $2.5^{\circ} \mathrm{C}$. Unique for 2010 was also that all months registered above-average temperatures; those of winter months January, February, November and December were $7-11^{\circ} \mathrm{C}$ above average, contributing significantly to the high annual-mean value as also determined for other west and south Greenland locations (Box et al., 2011; Van As et al., 2011). The months May, August, and December were the warmest of these particular months in the entire period, and April, September, and November ranked among the warmest three.

The extraordinary temperatures observed in Kangerlussuaq in 2010 are contrasted by those in 2009, which with an annual-mean value of $-4.7^{\circ} \mathrm{C}$, were close to the 1974 2010 reference norm. During the months April to August, the temperatures departed $0-0.8^{\circ} \mathrm{C}$ from their long-term averages, whereas September and October were about $1{ }^{\circ} \mathrm{C}$ colder than average. Thus, in terms of summer temperatures and length of the melt season, 2009 qualifies as a year that is representative of the mean 1974-2010 period, albeit somewhat cool compared to the 2001-2010 average. In this study, 2009 will serve as a reference for comparison against the anomalous year of 2010 .

In Fig. 3 the 2009 and 2010 near-surface temperatures over the ice sheet are compared at four different elevations above sea level $(500 \mathrm{~m}$ : lower ablation zone, $1000 \mathrm{~m}$ : middle ablation zone, $1500 \mathrm{~m}$ : equilibrium line altitude, and $2000 \mathrm{~m}$ : lower accumulation zone). The plot shows the results of the linear interpolation to the six weather stations in the Kangerlussuaq catchment. The (running-mean) 2010 temperatures exceeded those in the previous year throughout the year and at all elevations. During periods outside the high melt season (September to May), annual variability can be large, as seen in Figs. 2 and 3. Year-to-year differences during the highmelt months of June, July and August are commonly smaller, as evident from the smaller 2010 excess values in Fig. 3, because near-surface temperatures are strongly moderated by the proximity of the melting ice sheet surface. However, August 2010 was exceptional, especially in the higher regions of the transect where anomalously high temperatures prevailed. In the lower accumulation zone, temperatures exceeded 2009 temperatures by as much as $5^{\circ} \mathrm{C}$. Thus, the heat in the extreme month of August 2010 in Kangerlussuaq manifested in high near-surface temperatures at high elevation over the ice sheet, but not so much across the lower ice. However, as longwave radiation measurements will show below, freeatmospheric temperatures were high along the entire transect. This indicates that in regions where melt is common, an increase in free-atmospheric temperature only has a limited effect on near-surface temperature due to the moderating presence of the melting ice surface. Higher up the ice sheet where periods of sub-freezing temperatures regularly occur throughout the melt season, the mean response to warm weather will be greater. 


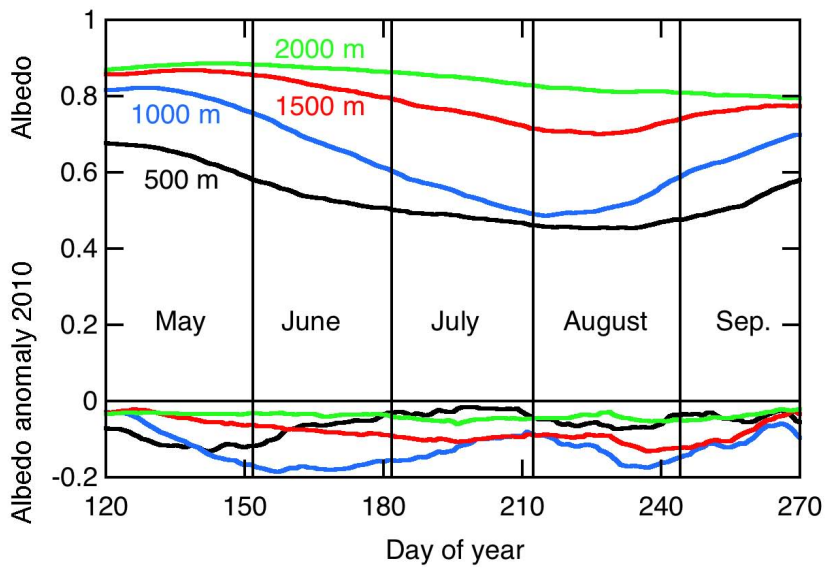

Fig. 4. Thirty-day running mean (calibrated) albedo at $500 \mathrm{~m}$ (black), $1000 \mathrm{~m}$ (blue), $1500 \mathrm{~m}$ (red) and $2000 \mathrm{~m}$ (green) elevation above sea level for the MODIS period (2000-2010). The lower lines give the 2010 albedo anomaly with identical colour coding.

\subsection{Surface albedo}

Surface albedo for the Kangerlussuaq catchment is investigated using MODIS satellite imagery. As expected, albedo increases with surface elevation, and drops as the melt season evolves (Fig. 4). Ice values (below $\sim 0.6$ ) are typical in the middle ablation zone at $1000 \mathrm{~m}$ elevation in the months July and August. In the lower ablation zone (500 m), albedo drops below 0.6 for four months, and rarely attains high "fresh snow" values since winter snowfall is low and also prone to drifting into crevasses leaving persistent patches of bare ice throughout the year (Van den Broeke et al., 2008).

Although Box et al. (2006) already reported negative albedo trends in the ablation zone of Greenland for 20002004, 2010 albedo is still considered anomalous, most notably in southwest Greenland (Tedesco et al., 2011). In the Kangerlussuaq catchment, (running-mean) calibrated albedo in 2010 was lower than the decadal average at all elevations throughout the melt season (lower panel in Fig. 4). In the lower and middle ablation zone $(500$ and $1000 \mathrm{~m})$, albedo was 0.1 below average already by May due to the early onset of melt, exposing bare ice before June (albedo below 0.6). Whereas in the lower ablation zone, albedo was near to normal values by July since high melt occurs here every year, at higher elevations it remained at least 0.1 below average until mid-September, causing up to $40 \%$ higher solar absorption rates than usual. In the upper ablation zone, the lowest 2010 albedo anomalies were attained in August, coincident with the high-elevation warm episode discussed in the previous section. Temperature and albedo anomalies enhance each other in the melt-albedo feedback: high temperatures cause high melt, lowering albedo due to enhanced surface metamorphosis, increasing solar radiation absorption, and further enhancing melt (e.g. Tedesco et al., 2011).

\subsection{Wintertime accumulation}

A third cause for extreme ablation in 2010 was relatively low wintertime accumulation (Tedesco et al., 2011). The greater the snow accumulation, the longer time and greater melting is required to expose the bare ice surface during the course of the melt season. In the Kangerlussuaq catchment, the effect is minor as the region is relatively arid due to orographic shielding of Sukkertoppen Icecap in the southwest, and significant wintertime snowdrift sublimation may occur (Van den Broeke et al., 2008). Burgess et al. (2010) report an annual-mean accumulation of 0 to $0.18 \mathrm{~m}$ of water equivalent in the lower region of the Kangerlussuaq catchment. The AWS measurements show that at KAN_M and S9 $\sim 0.6 \mathrm{~m}$ snow accumulated during the 2009/2010 winter, which is one third less than the previous year. So both years showed arid conditions compared to other regions of the ice sheet such as the south and southeast where several metres of snow can accumulate each year (Burgess et al., 2010). Whereas the lower amount of wintertime accumulation in the upper ablation zone, and possibly at higher elevation (measurements lacking), will have had some influence on the high 2010 melt, it is not as significant as the temperature and albedo effects mentioned above, given the relatively short time it takes to melt winter snow at the beginning of the summer melt season.

\subsection{Surface height change due to ablation and accumulation}

The measured time series of surface height change due to ablation and accumulation at the six weather stations is plotted in Fig. 5, along with the modelled values in the corresponding elevation bins. The time series commence in September 2008, when the three-station $K$-transect (S5, S6 and S9) was supplemented with KAN weather stations. Dashed coloured lines show model calculations that made use of the unaltered MODIS albedo product, and solid coloured lines represent model runs using calibrated MODIS albedo. The amount and time-evolution of ablation is modelled accurately, judging from the agreement between the measurements and model results making use of calibrated MODIS albedo input, especially at low elevation (S5 and KAN_L). Uncalibrated MODIS input produces larger ablation than what was measured at all sites, and exceeds the result with calibrated MODIS albedo by $14 \%$ at the lowest station and increasingly so with elevation. Since measured albedo at the weather stations as well as the overestimation of ablation without MODIS calibration suggest that the uncalibrated MODIS values are too low for this region, we will only focus on the calibrated MODIS results from hereon.

Minor mismatches exist between measured and modelled values, most notably at S6. A perfect agreement is not to be expected, as AWS provide point measurements, while the model yields values for areas of tens to hundreds of square 


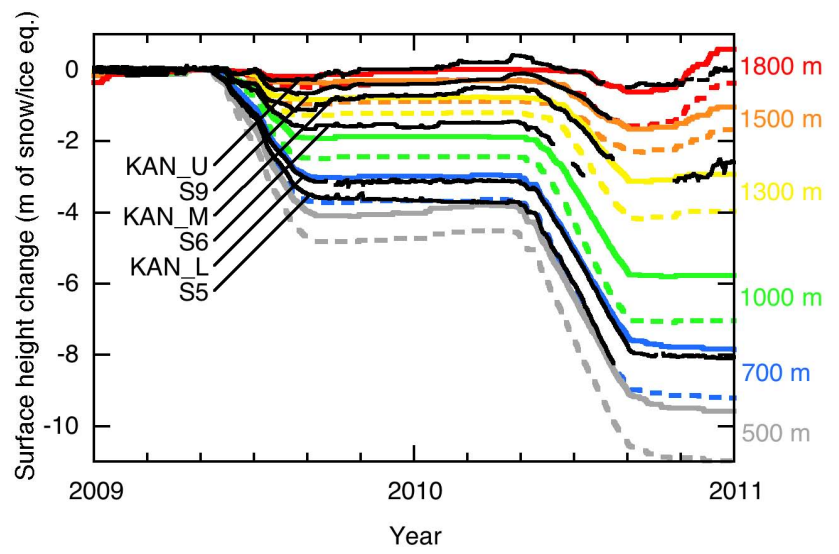

Fig. 5. Measured surface height change due to accumulation and ablation at the weather stations (black), and modelled values within the corresponding elevation bin (colours), with (solid) and without (dashed) MODIS albedo correction. N.B.: for late 2010, measured and modelled data series have been aligned after data gaps.

kilometres, with a mean elevation differing from those of the weather stations. This is particularly the case for albedo, the spatial variability of which can be large and cause considerable differences in ablation over short distances - which is why we use spatial distributions of MODIS-derived albedo in this study, and do not attempt to spatially interpolate this variable between AWS.

Based on the good correspondence between observed and modelled melt at each AWS, we have confidence in model performance and can investigate the differences in net ablation between 2009 and 2010. In 2009, net ablation at low elevations was $\sim 4 \mathrm{~m}$ of ice equivalent, which is a common value as documented by Van den Broeke et al. (2008), who measured an annual-mean ablation of $\sim 4.3 \mathrm{~m}$ ice eq. at $\mathrm{S} 5$ from 2004-2007, which were on average marginally warmer than 2009 (Fig. 2). Our ablation values for 2009 slightly exceed those for most years in a study by Mernild et al. (2010), who modelled meltwater runoff for the Kangerlussuaq catchment for 1979-2008, largely based on the off-ice DMI meteorological time series in Kangerlussuaq. In our results, $2010 \mathrm{ab}-$ lation ( $\sim 5 \mathrm{~m}$ at low elevation) exceeded all reported values from previous years. Figure 5 indicates that relative differences between 2009 and 2010 are larger in the upper ablation zone (green and yellow lines).

\subsection{Surface energy balance}

An advantage of SMB studies using energy balance modelling is that we can quantify the energy sources that contribute to ablation. Figure 6 illustrates the mean SEB components per elevation bin for June, July and August. Predictably, energy available for melt decreased with elevation, both in 2009 (dashed black line) and 2010 (solid black line), averaging at over $150 \mathrm{~W} \mathrm{~m}^{-2}$ in the lower ablation zone.

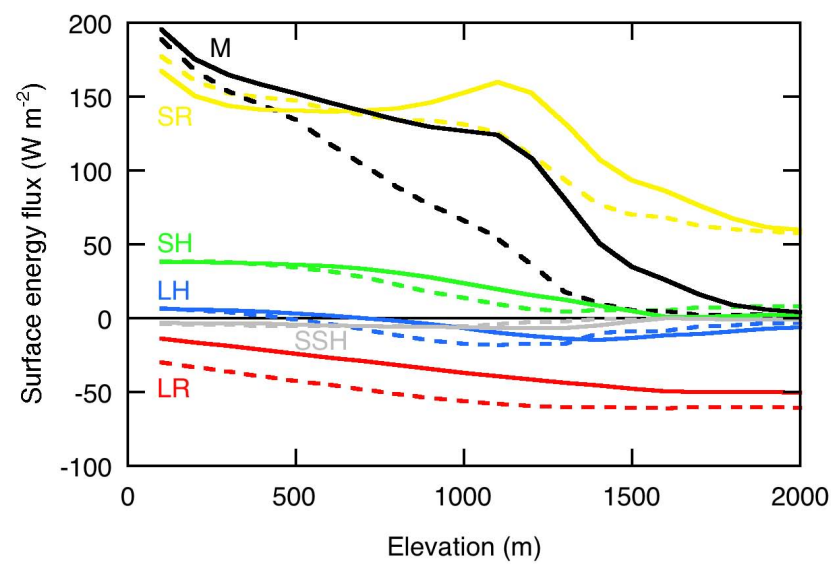

Fig. 6. Mean SEB components for June, July and August in 2009 (dashed lines) and 2010 (solid lines) versus elevation. Net shortwave radiation: yellow, net longwave radiation: red, sensible heat flux: green, latent heat flux: blue, sub-surface heat flux: grey, and energy available for melt: black.

This energy was mostly supplied by surface absorbed solar radiation (yellow lines), which typically decreases with elevation as albedo increases. Net longwave radiation is a heat sink over the entire domain, becoming more dominant in the energy balance with elevation, but never exceeding $-60 \mathrm{~W} \mathrm{~m}^{-2}$. The contrary is true for turbulent sensible heat exchange between atmosphere and ice sheet surface, decreasing from $\sim 40 \mathrm{~W} \mathrm{~m}^{-2}$ to near-zero mean values in the accumulation zone. Latent heat exchange represents only a small component over the domain in both summers (Fig. 6), peaking at around $-20 \mathrm{~W} \mathrm{~m}^{-2}$ in the upper ablation zone. The sub-surface heat flux is insignificant, with negative near-zero values at all elevations. The heat flux from rain is negligible and not plotted.

Large differences are evident between the mean energy balances in the summer of 2009 and 2010 (Fig. 6). Available melt energy was similar between both years in the very lower and upper elevation extremes of the domain, but in between, the 2010 melt energy exceeded that of our reference year 2009 , e.g. by over $70 \mathrm{~W} \mathrm{~m}^{-2}$ in the upper ablation zone around $1200 \mathrm{~m}$ elevation. Melt in 2010 exceeded 2009 totals by $44 \%$ when averaged over the entire elevation domain. In the lower ablation zone (below the $1000 \mathrm{~m}$ elevation bin), where ablation is large in all years, the excess melt was $19 \%$. In the upper ablation zone (1000-1400 m elevation bins), where generally less than $2 \mathrm{~m}$ ice eq. ablates each year, summer melt excess attained $\sim 170 \%$ in the three summer months.

In the lower ablation zone (below the $1000 \mathrm{~m}$ elevation bin), $74 \%$ of the excess melt can be attributed to increased net longwave radiation, i.e. larger emission from a warmer (or moister) atmosphere. The remainder of the energy was provided by increased turbulent heat fluxes, also as a result of higher atmospheric temperatures. The high 
correlation between downward longwave radiation and nearsurface temperature over Greenland was shown by, e.g. Fettweis (2007). In contrast, net shortwave radiation contributed $2.5 \mathrm{~W} \mathrm{~m}^{-2}$ less across the same region. The implication is that the 2010 melt excess in the lower ablation zone can be fully attributed to high temperatures, both near the surface and in the free atmosphere. We point out that Greenland's widest bare landmass $(160-170 \mathrm{~km})$ is adjacent to the Kangerlussuaq catchment, and that considerable amounts of atmospheric heat from solar warming of the tundra are advected from this region in summer. This contributes significantly to the heat budget of especially the lower parts of the ice sheet (Van den Broeke et al., 2011). Elsewhere in Greenland the closer proximity to cool coastal waters will have moderated the impact of the 2010 atmospheric temperature anomaly on ice sheet meltwater production.

In the upper ablation zone (1000-1400 m elevation bins), the excess melt energy mostly results from larger amounts of absorbed solar radiation (55\%), but a significant share (49\%) still originates from the energy fluxes sensitive to air temperature. The surplus energy $(4 \%)$ was drained by the sub-surface heat flux, which was more negative in 2010 than in 2009. These results are confirmed by Tedesco et al. (2011), who identify high temperatures and low albedo as the basis of the 2010 melt anomaly, facilitated by low wintertime accumulation in southwest Greenland. Tedesco et al. (2008) draw similar conclusions for 2007, also a year of record melt on the Greenland ice sheet, and identified as a high-frequency melt year by Van den Broeke et al. (2011). The latter confirm the occurrence of the 2007 and 2010 melt anomalies in the upper ablation zone (S9), chiefly due to the melt - albedo feedback. Van den Broeke et al. (2011) also confirm that interannual melt variability in the lower ablation zone is driven by the variability in the turbulent flux of sensible heat, as is the case in our study.

The altitude-area distribution of the Kangerlussuaq catchment increases rapidly with elevation, because the ice surface is steeper near the margin and is channelled into numerous discrete outlet glaciers (black lines in Fig. 7). For instance, the $500 \mathrm{~m}$ elevation bin has a surface area of $62 \mathrm{~km}^{2}$, while the $1000 \mathrm{~m}$ bin area is $185 \mathrm{~km}^{2}$. This implies that 2010 melt, which was most extreme in the higher regions of the ablation zone, was of larger relative significance than is apparent from Fig. 5. This also means that the area in which albedo was the (slightly) more dominant cause of the melt anomaly is much larger than the area in which this was valid for temperature.

\subsection{Surface meltwater production}

Integrating the daily runoff values as calculated per elevation bin over the Kangerlussuaq catchment provides the total surface meltwater runoff, as plotted in Fig. 8 for 2009 and 2010 (black lines). Surface meltwater runoff started early in 2010 (late April) and was larger than in 2009 throughout almost the entire melt season. Whereas 2009 only had

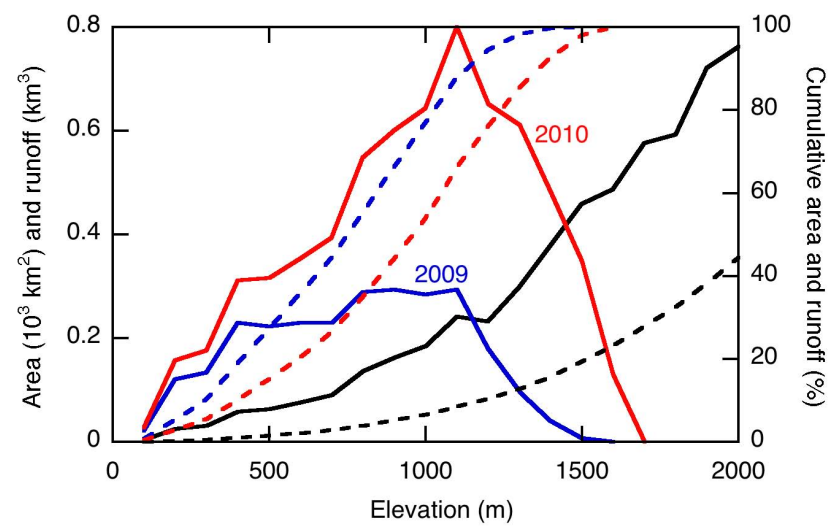

Fig. 7. Kangerlussuaq catchment surface area (black), and surface meltwater runoff for 2009 (blue) and 2010 (red) per elevation bin. Dashed lines illustrate cumulative values.

a single distinct melt peak in mid-July (days 190-200), the 2010 record illustrates large melt over a four-month period, peaking late July/early August. The runoff during the peak of the melt season in $2009\left(0.10 \mathrm{~km}^{3} \mathrm{day}^{-1}\right)$, however, is not much smaller than in $2010\left(0.11 \mathrm{~km}^{3} \mathrm{day}^{-1}\right)$. Note the largest modelled runoff $\left(0.12 \mathrm{~km}^{3} \mathrm{day}^{-1}\right)$ took place during the end of the 2010 melt season on 2 September, during which MODIS albedo was low especially at low elevation, e.g. 0.17 in the $500 \mathrm{~m}$ elevation bin, and temperature attained the highest value of the year over the catchment area (and third highest in Kangerlussuaq). We calculate the total surface meltwater runoff for the Kangerlussuaq catchment to be $2.7 \pm 0.4 \mathrm{~km}^{3}$ for 2009 , and $6.6 \pm 1.0 \mathrm{~km}^{3}$ for $2010(\sim 150 \%$ larger).

The annual surface meltwater totals per elevation bin (Fig. 7) indicate that even though energy available for melt decreased with elevation; the peak meltwater in meltwater production is located at roughly $1000 \mathrm{~m}$ elevation due to the increasing surface area with elevation over the ice sheet. As expected from the energy available for melt in Fig. 6, the meltwater runoff totals in 2009 (blue) were exceeded by those in 2010 (red) at all elevations (Fig. 7). However, because the elevation bins get increasingly large with elevation, also the meltwater excess increased with elevation. There is a large $\sim 200 \mathrm{~m}$ shift of the elevation of mean meltwater production: from $700-800 \mathrm{~m}$ to $900-1000 \mathrm{~m}$ above sea level from 2009 to 2010. Such a shift increases the ablation area by roughly $50 \%$. Applying a $+200 \mathrm{~m}$ vertical shift to the 2009 melt would increase surface meltwater runoff by $\sim 60 \%$, thus explaining about $40 \%$ of the 2010 catchmentwide runoff excess. This illustrates that the hypsometry of the ice sheet greatly amplifies melt anomalies.

The meltwater that runs off is transported englacially and subglacially to the ice sheet margin via a network of surface channels, melt lakes, moulins and crevasses. Moulins form and re-activate annually virtually everywhere in the ablation 


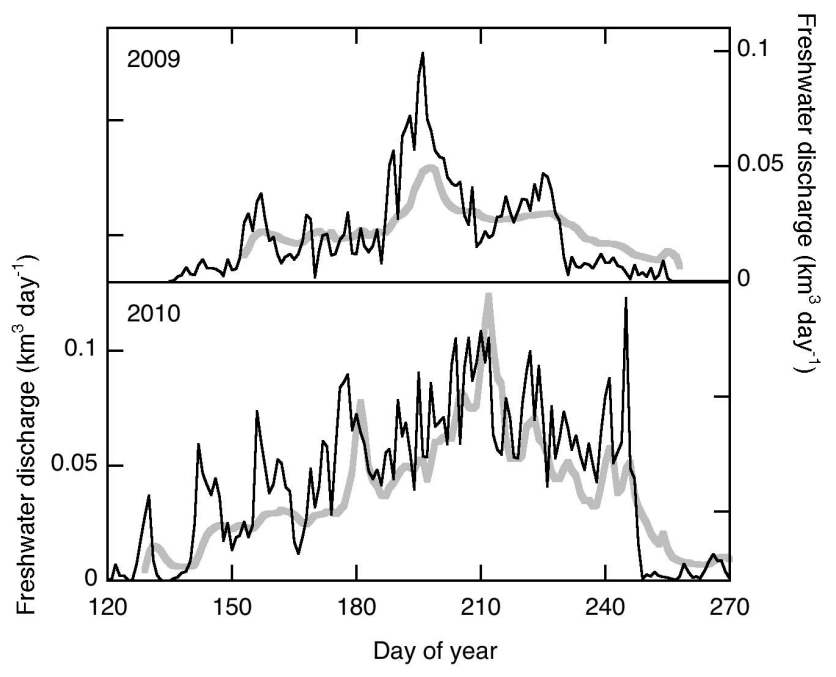

Fig. 8. Calculated daily totals of surface meltwater runoff for the Kangerlussuaq catchment (black) and the freshwater flux estimated from river depth measurements (grey) for 2009 and 2010.

zone of the Kangerlussuaq catchment, readily draining available surface water. After passage through and underneath the ice sheet, meltwater collects in the proglacial melt river that runs past Kangerlussuaq. The freshwater discharge as measured at the bridge over Watson River in Kangerlussuaq is also illustrated in Fig. 8.

There is good agreement between the calculated meltwater runoff and measured freshwater discharge in terms of absolute values and timing of peaks $(r=0.84$ for 2009 and 0.74 for 2010). The total discharge, as estimated from calculations at the bridge, is $2.5 \pm 0.5 \mathrm{~km}^{3}$ for 2009 and $5.3 \pm 1.1 \mathrm{~km}^{3}$ for 2010 , respectively 8 and $19 \%$ percent lower than the calculated meltwater runoff. Although the difference can be explained by the measurement and modelling uncertainty in both records, we should point out that the discharge measurements do not cover the entire melt season, and thus its yearly total will be a lower estimate. Also, the runoff values for the glacier do not consider the sinks and sources in the proglacial tundra, such as precipitation, evaporation, and interaction with groundwater. A further source of mismatch between the two records is potential storage in supra- and sub-glacial melt lakes, including the ice-dammed marginal lake as documented by Russell et al. (2011).

Most importantly though, basal topography is a first order control on subglacial meltwater routing, as a dense network of moulins across the ablation zone captures local melt water (Bartholomew et al., 2011). In this and similar studies, the surface topography alone is used for catchment delineation, given the lack of a detailed knowledge of basal topography. As Van de Wal and Russell (1994) already concluded, an uncertainty in meltwater runoff estimates remains due to missing information on the exact extent of the subglacial catchment. Our glacier surface catchment area $\left(12574 \mathrm{~km}^{2}\right)$ is larger than that reported in previous studies, such as by Mernild et al. (2010) $\left(6130 \mathrm{~km}^{2}\right)$ and Hasholt et al. (2012) $\left(9743 \mathrm{~km}^{2}\right)$. Given that our 2010 runoff total exceeds the estimated discharge value more than in 2009, and more meltwater originated from a higher elevation in 2010, this could be an indication that the actual drainage area includes less of the upper catchment than assumed in this study. For this reason we conducted an experiment in which we reduced the surface area of each elevation bin over $1000 \mathrm{~m}$ elevation by $10 \%$ more than its lower neighbour (i.e. $10 \%$ for the $1100 \mathrm{~m}$ bin, $20 \%$ for the $1200 \mathrm{~m}$ bin, etc.), effectively reducing the catchment area by $80 \%$. Below $1000 \mathrm{~m}$ elevation we can safely assume our catchment delineation to be accurate based on the close proximity to the ice margin. The highly substantial area reduction resulted in only $4 \%$ and $13 \%$ smaller surface meltwater runoff totals for 2009 and 2010, respectively, indicating low sensitivity to catchment size and increasing confidence in our results.

Close examination of the timing of the bulk surface meltwater runoff and Watson River discharge peaks reveals a phase difference between the two (Fig. 8), caused by transport delays through the ice sheet and proglacial river systems. In 2010, the Watson River discharge became markedly more variable after peak seasonal melt, closely following the calculated surface meltwater runoff. This is expected for an evolving glacial drainage system, which generally becomes more efficient as its size and capacity increases until meltwater availability falls in August (Fig. 8). The meltwater conduits do not close fast enough to disallow efficient passage of meltwater during the remainder of the melt season. This is also concluded from sub-glacial water pressure measurements in the region, which produced high values before the peak of the melt season and lower ones after (Harper et al., 2010). Also, there is an upglacier expansion and increase in hydraulic efficiency of the subglacial drainage system during the melt season as recently reported on by Bartholomew et al. (2011). The link between meltwater production, basal pressure, and ice velocity has been subject of several studies in recent years for the Kangerlussuaq region (Bartholomew et al., 2010, 2011; Palmer et al., 2011; Sundal et al., 2011). The result here over a larger catchment than considered in these studies tantalisingly indicates that there does indeed appear to be an evolution in drainage efficiency over the season, though disaggregating this effect from compounding factors such snow percolation rates, short and long-term surface and englacial storage, and distance from source to sink require detailed analysis beyond the scope of this study.

\section{Conclusions}

In 2010, atmospheric temperatures were record-setting over much of Greenland. In Kangerlussuaq in southwest Greenland, the annual-mean temperature was 2.7 standard deviations above the 1974-2010 average. Over the ice sheet 
temperatures also exceeded the near-average year 2009 throughout the melt season, particularly in the upper ablation zone and lower accumulation zone and the record-warm month of August.

Due to the early onset of melt in 2010, combined with lower winter accumulation, surface albedo was below the 2000-2010 average as determined from calibrated MODIS imagery. This in turn allowed for larger solar radiation absorption, resulting in higher melt (melt-albedo feedback). As a consequence, energy available for surface melt was larger in 2010 than in 2009, particularly in the upper ablation zone. While the warmer atmosphere caused increased melt over the entire elevation domain, in the upper ablation zone the relatively low albedo allowed for higher solar radiation absorption rates, contributing over half to the melt increase.

The modelled meltwater runoff from the Kangerlussuaq catchment agrees well with discharge measurements taken in the proglacial river system at the bridge in Kangerlussuaq $(r=0.79)$ and provides good corroboration of the well constrained modelling effort. Whilst the bulk melt hydrograph in 2009 was characterized by a single outstanding peak, 2010 experienced sustained, high magnitude meltwater production for roughly three months. Runoff for the entire Kangerlussuaq catchment in 2010 was $\sim 150 \%$ larger than the previous year. This value is almost as large as the melt excess for the upper ablation zone $(\sim 170 \%)$ due to the specific catchment hypsometry, which dictates that, although melt rate and runoff are proportionally decreasing with elevation, this is offset by the rapid increase in contributing area. Roughly $40 \%$ of the 2010 catchment-wide runoff excess can be attributed to a $+200 \mathrm{~m}$ vertical shift of melt alone.

During warm episodes in the future, a melt response of at least this magnitude should be expected unless large wintertime snowfall offsets the melt-albedo feedback. Frequent high-magnitude melt years drive a positive feedback as snow and firn surfaces ablate in the upper catchment, thereby exposing bare ice and reducing albedo, further enhancing any melt response. This is further amplified by the hypsometry of the ice sheet, dictating that the increase in the affected ice sheet area will be substantial and not be proportional to the increase in melt forcings.

Acknowledgements. Funding for this work was provided by the Greenland Analogue Project (GAP), a collaborative project funded by the nuclear waste management organizations in Sweden (Svensk Kärnbränslehantering $\mathrm{AB}$ ), Finland (Posiva Oy) and Canada (NWMO). The surface melt component of GAP is run in collaboration with the Programme for Monitoring of the Greenland Ice Sheet (PROMICE). This is a PROMICE publication. Fieldwork logistics were co-funded by NERC (NE/G005796/1) and C3W. We thank Jason Box for numerous text edits in the review process.

Edited by: J. L. Bamber

\section{References}

Bartholomew, I., Nienow, P., Mair, D., Hubbard, A., King, M. A., and Sole, A.: Seasonal evolution of subglacial drainage and acceleration in a Greenland outlet glacier, Nat. Geosci., 3, 408-411, 2010.

Bartholomew, I., Nienow, P., Sole, A., Mair, D., Cowton, T., Palmer, S., and Wadham J.: Supraglacial forcing of subglacial hydrology in the ablation zone of the Greenland Ice Sheet, Geophys. Res. Lett., 38, L08502, doi:10.1029/2011GL047063, 2011.

Boas, L. and Riddersholm Wang, P.: Weather and climate data from Greenland 1958-2010, DMI Technical Report No. 11-15, Copenhagen, 2011.

Box, J. E.: Survey of Greenland instrumental temperature records: 1873-2001. Int. J. Climatol., 22, 1829-1847, 2002.

Box, J. E., Bromwich, D. H., Veenhuis, B. A., Bai, L. S., Stroeve, J. C., Rogers, J. C., Steffen, K., Haran, T., and Wang, S. H.: Greenland ice sheet surface mass balance variability (1988-2004) from calibrated Polar MM5 output, J. Climate, 19, 2783-2800, 2006.

Box, J. E., Ahlstrøm, A., Cappelen, J., Fettweis, X., Decker, D., Mote, T., Van As, D., Van de Wal, R. S. W., Vinther, B., and Wahr, J.: Greenland, in: State of the Climate in 2010, B. Am. Meteorol. Soc., 92, 161-171, 2011.

Brock, B. W., Willis, I. C., and Shaw, M. J.: Measurement and parameterization of aerodynamic roughness length variations at Haut Glacier d'Arolla, Switzerland, J. Glaciol., 52, 281-297, 2006.

Burgess, E. W., Forster, R. R., Box, J. E., Mosley-Thompson, E., Bromwich, D. H., Bales, R. C., and Smith, L. C.: A spatially calibrated model of annual accumulation rate on the Greenland Ice Sheet (1958-2007), J. Geophys. Res., 115, F02004, doi:10.1029/2009JF001293, 2010.

Csatho, B., Schenk, T., Van der Veen, C. J., and Krabill, W. B.: Intermittent thinning of Jakobshavn Isbrae, West Greenland, since the Little Ice Age, J. Glaciol., 54, 131-144, 2008.

Fettweis, X.: Reconstruction of the 1979-2006 Greenland ice sheet surface mass balance using the regional climate model MAR, The Cryosphere, 1, 21-40, doi:10.5194/tc-1-21-2007, 2007.

Hall, D. K., Riggs, G. A., and Salomonson, V. V.: MODIS/Terra Snow Cover Daily L3 Global 500 m Grid V005, [2000-2010], Boulder, Colorado USA: National Snow and Ice Data Center, Digital media, updated daily, 2006.

Harper, J. T., Humphrey, N. F., Johnson, J. V., Meierbachtol, T. W., Brinkerhoff, D. J., and Landowski, C. M.: Integrating Borehole Measurements with Modeling of Englacial and Basal Conditions, Western Greenland, Abstract C42A-03 presented at 2010 Fall Meeting, AGU, San Francisco, CA, USA, 13-17 December, 2010.

Hasholt, B., Mikkelsen, A. B., Nielsen, M. H., and Larsen, M. A. D.: Observations of Runoff and Sediment and Dissolved Loads from the Greenland Ice Sheet at Kangerlussuaq, West Greenland, 2007 to 2010, submitted to Z. Geomorphol., 2012.

Howat, I. M., Ahn, Y., Joughin, I., Van den Broeke, M. R., Lenaerts, J. T. M., and Smith, M.: Mass balance of Greenland's three largest outlet glaciers, 2000-2010, Geophys. Res. Lett., 38, L12501, doi:10.1029/2011GL047565, 2011.

Khan, S. A., Wahr, J., Bevis, M., Velicogna, I., and Kendrick, E.: Spread of ice mass loss into northwest Greenland observed by GRACE and GPS, Geophys. Res. Lett., 37, L06501, doi:10.1029/2010GL042460, 2010. 
Klein, A. G. and Stroeve, J.: Development and validation of a snow albedo algorithm for the MODIS instrument, Ann. Glaciol., 34, 45-52, 2002.

Mernild, S. H., Liston, G. E., Steffen, K., van den Broeke, M., and Hasholt, B.: Runoff and mass-balance simulations from the Greenland Ice Sheet at Kangerlussuaq (Søndre Strømfjord) in a 30-year perspective, 1979-2008, The Cryosphere, 4, 231-242, doi:10.5194/tc-4-231-2010, 2010.

Palmer, S., Shepherd, A., Nienow, P., and Joughin, I.: Seasonal speedup of the Greenland Ice Sheet linked to routing of surface water, Earth Planet. Sc. Lett., 302, 423-428, 2011.

Pritchard, H. D., Arthern, R. J., Vaughan, D. G., and Edwards, L. A.: Extensive dynamic thinning on the margins of the Greenland and Antarctic ice sheets, Nature, 461, 971-975, 2009.

Rignot, E. and Kanagaratnam, P.: Changes in the velocity structure of the Greenland ice sheet, Science, 311, 986-990, 2006.

Russell, A. J., Carrivick, J. L., Ingeman-Nielsen, T., Yde, J. C., Williams, M.: A new cycle of jökulhlaups at Russell Glacier, Kangerlussuaq, West Greenland, J. Glaciol., 57, 238-46, 2011.

Schaaf, C. B., Wang, Z., and Strahler, A. H.: Commentary on Wang and Zender - MODIS snow albedo bias at high solar zenith angles relative to theory and to in situ observations in Greenland, Remote Sens. Environ., 115, 1296-1300, 2011.

Schrama, E., Wouters, B., and Vermeersen, B.: Present day regional mass loss of Greenland observed with satellite gravimetry, Surv. Geophys., 32, 377-385, doi:10.1007/s10712-011-9113-7, 2011.

Smeets, C. J. P. P. and Van den Broeke, M. R.: Temporal and spatial variation of momentum roughness length in the ablation zone of the Greenland ice sheet, Bound.-Lay. Meteorol., 128, 315-338, 2008.

Stroeve, J. C., Box, J. E., and Haran, T.: Evaluation of the MODIS (MOD10A1) daily snow albedo product over the Greenland ice sheet, Remote Sens. Environ., 105, 155-171, 2006.

Sundal, A. V., Shepherd, A., Nienow, P., Hanna, E., Palmer, S., and Huybrechts, P.: Melt-induced speed-up of Greenland ice sheet offset by efficient subglacial drainage, Nature, 469, 521-524, doi:10.1038/nature09740, 2011.

Tedesco, M., Serreze, M., and Fettweis, X.: Diagnosing the extreme surface melt event over southwestern Greenland in 2007, The Cryosphere, 2, 159-166, doi:10.5194/tc-2-159-2008, 2008.

Tedesco, M., Fettweis, X., Van den Broeke, M. R., Van de Wal, R. S. W., Smeets, C. J. P. P., Van de Berg, W. J., Serreze, M. C., and Box, J. E.: The role of albedo and accumulation in the 2010 melting record in Greenland, Environ. Res. Lett., 6, 014005, doi:10.1088/1748-9326/6/1/014005, 2011. van As, D.: Warming, glacier melt and surface energy budget from weather station observations in the Melville Bay region of northwest Greenland, J. Glaciol., 57, 208-220, 2011.

van As, D., Fausto, R. S., and the PROMICE project team: Programme for Monitoring of the Greenland Ice Sheet (PROMICE): first temperature and ablation records, Geol. Surv. Den. Greenl., 23, 73-76, 2011.

van de Wal, R. S. W. and Russell, A. J.: A comparison of energy balance calculations, measured ablation and meltwater runoff near Søndre Strømfjord, West Greenland, Global Planet. Change, 9, 29-38, 1994.

van de Wal, R. S. W., Gruell, W., Van den Broeke, M. R., Reijmer, C. H., and Oerlemans, J.: Surface mass-balance observations and automatic weather station data along a transect near Kangerlussuaq, West Greenland, Ann. Glaciol., 42, 311-316, 2005.

van den Broeke, M. R., Van As, D., Reijmer, C. H., and Van de Wal, R. S. W.: Assessing and improving the quality of unattended radiation observations in Antarctica, J. Atmos. Ocean. Tech., 21, 1417-1431, 2004.

van den Broeke, M. R., Smeets, P., Ettema, J., van der Veen, C., van de Wal, R., and Oerlemans, J.: Partitioning of melt energy and meltwater fluxes in the ablation zone of the west Greenland ice sheet, The Cryosphere, 2, 179-189, doi:10.5194/tc-2-179-2008, 2008.

van den Broeke, M. R., Bamber, J., Ettema, J., Rignot, E., Schrama, E., Van de Berg, W. J., Van Meijgaard, E., Velicogna, I., and Wouters, B.: Partitioning recent Greenland mass loss, Science, 326, 984-986, 2009.

van den Broeke, M. R., Smeets, C. J. P. P., and van de Wal, R. S. W.: The seasonal cycle and interannual variability of surface energy balance and melt in the ablation zone of the west Greenland ice sheet, The Cryosphere, 5, 377-390, doi:10.5194/tc-5-377-2011, 2011.

Wang, X. and Zender C. S.: MODIS snow albedo bias at high solar zenith angles relative to theory and to in situ observations in Greenland, Remote Sens. Environ., 114, 563-575, 2010. 